\title{
Zinc-Catalyzed Asymmetric Aldol Additions of Methyl Ynones. A Case of Spontaneous Reversal in the Sense of Enantioinduction
}

\author{
Barry M. Trost, ${ }^{*}$ Alec Fettes, and Brock T. Shireman \\ Department of Chemistry, Stanford University, Stanford, California 94305-5080
}

\section{Supplementary Information}

${ }_{\mathrm{EtO}}^{\mathrm{Me}} \mathrm{OEt}_{\mathrm{OEt}}^{\mathrm{O}}$

2,2-Diethoxy-propionic acid ethyl ester. To ethyl pyruvate $(26.5 \mathrm{~g}, 25.0 \mathrm{~mL}$, $228.0 \mathrm{mmol}$,) was added $\mathrm{EtOH}(90 \mathrm{~mL})$, ethylorthoformate $(90 \mathrm{~mL})$, and $\mathrm{H}_{2} \mathrm{SO}_{4}$ $(0.5 \mathrm{~mL})$. The mixture was stirred at room temperature for $14 \mathrm{~h}$ and then portioned between $\mathrm{Et}_{2} \mathrm{O}(200 \mathrm{~mL})$ and saturated aqueous $\mathrm{NaHCO}_{3}(100 \mathrm{~mL})$. The layers were separated and the aqueous layer was extracted with $\mathrm{Et}_{2} \mathrm{O}(200 \mathrm{~mL})$. The combined organic layers were washed with brine, dried over anhydrous $\mathrm{MgSO}_{4}$, filtered, and concentrated under reduced pressure to give a light yellow oil. Vacuum distillation (30 Torr) provided $43.4 \mathrm{~g}(79 \%)$ of the title compound as a clear liquid $\left(100-105^{\circ} \mathrm{C}\right) .{ }^{1} \mathrm{H}$ NMR $\left(\mathrm{CDCl}_{3}, 500 \mathrm{MHz}\right) \delta 1.24(\mathrm{t}, \mathrm{J}=7.0 \mathrm{~Hz}, 6 \mathrm{H})$, $1.32(\mathrm{t}, J=7.0 \mathrm{~Hz}, 3 \mathrm{H}), 1.54(\mathrm{~s}, 3 \mathrm{H}), 3.46-3.52(\mathrm{~m}, 2 \mathrm{H}), 3.56-3.63(\mathrm{~m}, 2 \mathrm{H}), 4.26(\mathrm{q}, J=7.0 \mathrm{~Hz}$, $2 \mathrm{H}) ;{ }^{13} \mathrm{C} \mathrm{NMR}\left(\mathrm{CDCl}_{3}, 75 \mathrm{MHz}\right) \delta 15.3,18.8,57.6,100.3,199.6$.

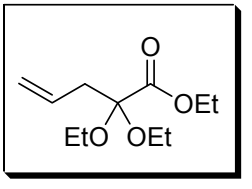

2,2-Diethoxy-pent-4-enoic acid ethyl ester. To diisopropyl amine (5.67 g, $6.46 \mathrm{~mL}, 46.1 \mathrm{mmol})$ in THF $(50 \mathrm{~mL})$ at $-78^{\circ} \mathrm{C}$ was added $n$-BuLi $(31.4 \mathrm{~mL}$, $1.4 \mathrm{M}$ in hexanes, $44.0 \mathrm{mmol}$ ). The solution was warmed to $0{ }^{\circ} \mathrm{C}$ for $20 \mathrm{~min}$, then recooled to $-78{ }^{\circ} \mathrm{C}$ and diethoxy ethylacetate $(7.4 \mathrm{~g}, 7.5 \mathrm{~mL}, 41.9 \mathrm{mmol})$ was added dropwise over $10 \mathrm{~min}$. The solution was warmed to $0{ }^{\circ} \mathrm{C}$ for $30 \mathrm{~min}$ then recooled to $-78{ }^{\circ} \mathrm{C}$ and allyl bromide $(5.58 \mathrm{~g}, 3.90 \mathrm{~mL}, 46.1 \mathrm{mmol})$ was added dropwise over $10 \mathrm{~min}$. The reaction was warmed to $0{ }^{\circ} \mathrm{C}$ for $3 \mathrm{~h} 15$ min then partitioned between $1 \mathrm{~N}$ aqueous $\mathrm{HCl}(75 \mathrm{~mL})$ and $\mathrm{Et}_{2} \mathrm{O}$ $(80 \mathrm{~mL})$. The layers were separated and the aqueous layer was extracted with $\mathrm{Et}_{2} \mathrm{O}(80 \mathrm{~mL})$. The combined organics were washed with saturated aqueous $\mathrm{NaHCO}_{3}$ and brine, then dried over anhydrous $\mathrm{MgSO}_{4}$, filtered, and concentrated under reduced pressure to give a clear liquid that was purified by silica gel chromatography eluting with $35 \% \mathrm{Et}_{2} \mathrm{O}$ in pet. ether to give $5.9 \mathrm{~g}$ (59\%) of the title compound as a clear liquid. IR (neat) 3081, 2979, 2892, 1748, 1643, 1445, 
$1316 \mathrm{~cm}^{-1} ;{ }^{1} \mathrm{H}$ NMR $\left(300 \mathrm{MHz}, \mathrm{CDCl}_{3}\right) \delta 1.24(\mathrm{t}, J=7.2 \mathrm{~Hz}, 6 \mathrm{H}), 1.29(\mathrm{t}, J=7.2 \mathrm{~Hz}, 3 \mathrm{H}), 2.67$ (dd, $J=1.2,7.2 \mathrm{~Hz}, 2 \mathrm{H}), 3.44-3.54(\mathrm{~m}, 2 \mathrm{H}), 3.55-3.65(\mathrm{~m}, 2 \mathrm{H}), 4.24(\mathrm{q}, J=7.2 \mathrm{~Hz}, 3 \mathrm{H}), 5.07(\mathrm{~s}, 1 \mathrm{H})$, 5.10-5.13 (m, 1H), 5.63-5.76 (m, 1H); ${ }^{3} \mathrm{C}$ NMR (75 MHz, $\left.\mathrm{CDCl}_{3}\right) \delta 168.7,131.0,118.6,101.4$, 61.1, 57.7, 39.2, 15.0, 14.1; Anal. Calc'd for $\mathrm{C}_{11} \mathrm{H}_{20} \mathrm{O}_{4}$ : C, 61.09; H, 9.32. Found: C, 61.21; $\mathrm{H}$, 9.16 .

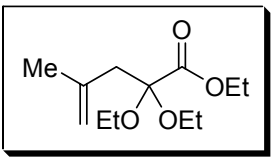

2,2-Diethoxy-4-methyl-pent-4-enoic acid ethyl ester. To tetramethylpiperidine $(2.83 \mathrm{~g}, 3.4 \mathrm{~mL}, 20.0 \mathrm{mmol})$ in $\mathrm{THF}(20 \mathrm{~mL})$ at $0{ }^{\circ} \mathrm{C}$ was added $n$-BuLi (8.0 mL, $2.4 \mathrm{M}$ in hexanes, 19.2mmol). After $20 \mathrm{~min}$ the solution was cooled to $-78{ }^{\circ} \mathrm{C}$ and diethoxy ethylacetate $(3.0 \mathrm{~g}, 3.05 \mathrm{~mL}, 17.0 \mathrm{mmol})$ was added dropwise over $10 \mathrm{~min}$. The solution was warmed to $0{ }^{\circ} \mathrm{C}$ for $30 \mathrm{~min}$ then recooled to $-78{ }^{\circ} \mathrm{C}$ and methallyl bromide $(2.98 \mathrm{~g}, 2.30 \mathrm{~mL}, 22.1 \mathrm{mmol})$ was added dropwise over $10 \mathrm{~min}$. The reaction was warmed to $0{ }^{\circ} \mathrm{C}$ for $3 \mathrm{~h}$, then partitioned between $1 \mathrm{~N}$ aqueous $\mathrm{HCl}(50 \mathrm{~mL})$ and $\mathrm{Et}_{2} \mathrm{O}$. The layers were separated and the aqueous layer was extracted with $\mathrm{Et}_{2} \mathrm{O}$. The combined organics were washed with saturated aqueous $\mathrm{NaHCO}_{3}$ and brine, then dried over $\mathrm{MgSO}_{4}$, filtered, and concentrated under reduced pressure to give a clear liquid that was purified by silica gel chromatography eluting with $35 \% \mathrm{Et}_{2} \mathrm{O}$ in pet. ether to give $2.47 \mathrm{~g}(63 \%)$ of the title compound as a clear liquid. IR (neat) 3078, 2979, 2933, 1752, 1647, 1445, 1391, $1197 \mathrm{~cm}^{-1}$; ${ }^{1} \mathrm{H}$ NMR $\left(300 \mathrm{MHz} \mathrm{CDCl}_{3}\right) \delta 1.23(\mathrm{t}, J=7.2 \mathrm{~Hz}, 6 \mathrm{H}), 1.29(\mathrm{t}, J=7.2 \mathrm{~Hz}, 3 \mathrm{H}), 1.76(\mathrm{~s}, 3 \mathrm{H}), 2.63(\mathrm{~s}, 2 \mathrm{H})$, 3.43-3.53 (m, 2H), 3.55-3.65 (m, 2H), $4.21(\mathrm{q}, J=7.2 \mathrm{~Hz}, 2 \mathrm{H}), 4.79(\mathrm{~m}, 2 \mathrm{H}) ;{ }^{13} \mathrm{C}$ NMR $\left(75 \mathrm{MHz}, \mathrm{CDCl}_{3}\right) \delta 168.9,139.9,114.5,101.9,61.1,57.7,42.4,23.1,15.1,14.1$; Anal. Calc'd for $\mathrm{C}_{12} \mathrm{H}_{22} \mathrm{O}_{4}: \mathrm{C}, 62.58 ; \mathrm{H}, 9.63$ Found: $\mathrm{C}, 62.72 ; \mathrm{H}, 9.64$.

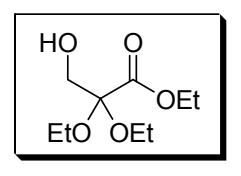

2,2-Diethoxy-3-hydroxy-propionic acid ethyl ester. To tetramethylpiperidine $(12.6 \mathrm{~g}, 15.0 \mathrm{~mL}, 89.0 \mathrm{mmol})$ in THF $(75 \mathrm{~mL})$ at $0{ }^{\circ} \mathrm{C}$ was added $n$-BuLi $(37 \mathrm{~mL}$, $2.2 \mathrm{M}$ in hexanes, $81.4 \mathrm{mmol})$. After $20 \mathrm{~min}$ the solution was cooled to $-78{ }^{\circ} \mathrm{C}$ and diethoxy ethylacetate $(3.0 \mathrm{~g}, 3.05 \mathrm{~mL}, 17.0 \mathrm{mmol})$ was added dropwise over $10 \mathrm{~min}$. After $45 \mathrm{~min}$, the solution was warmed to $0^{\circ} \mathrm{C}$ for $15 \mathrm{~min}$ and paraformaldehyde $(4.4 \mathrm{~g}, 14.8 \mathrm{mmol})$ was added in one portion. The reaction was partitioned between $0.5 \mathrm{M}$ aqueous $\mathrm{H}_{2} \mathrm{SO}_{4}$ $(100 \mathrm{~mL})$ and $\mathrm{Et}_{2} \mathrm{O}(200 \mathrm{~mL})$. The layers were separated and the aqueous layer was extracted with $\mathrm{Et}_{2} \mathrm{O}(4 \times 100 \mathrm{~mL})$. The combined organics were washed with saturated aqueous $\mathrm{NaHCO}_{3}$ and brine, then dried over anhydrous $\mathrm{MgSO}_{4}$, filtered, and concentrated under reduced pressure to give a yellow liquid that distilled under vacuum (5 Torr) collecting the material 
distilling at $85-95{ }^{\circ} \mathrm{C}$ to give $9.0 \mathrm{~g} \mathrm{(59 \% )}$ of the title compound as a white solid. IR (neat) 3499 , 2980, 2936, 2899, 1746, 1395, 1084cm ${ }^{-1} ;{ }^{1} \mathrm{H}$ NMR (300 MHz, $\left.\mathrm{CDCl}_{3}\right) \delta 1.25(\mathrm{t}, \mathrm{J}=7.2 \mathrm{~Hz}, 6 \mathrm{H})$, $1.33(\mathrm{t}, J=6.9 \mathrm{~Hz}, 3 \mathrm{H}), 1.92(\mathrm{t}, J=6.3 \mathrm{~Hz}, 1 \mathrm{H}), 3.52-3.70(\mathrm{~m}, 4 \mathrm{H}), 3.82(\mathrm{~d}, J=6.3 \mathrm{~Hz}, 2 \mathrm{H}), 4.29$ $(\mathrm{q}, J=6.9 \mathrm{~Hz}, 2 \mathrm{H}) ;{ }^{13} \mathrm{C}$ NMR $\left(75 \mathrm{MHz}, \mathrm{CDCl}_{3}\right) \delta 168.3,100.5,63.2,61.8,58.4,15.2$, 14.2; Anal. Calc'd for $\mathrm{C}_{9} \mathrm{H}_{18} \mathrm{O}_{5}: \mathrm{C}, 52.41 ; \mathrm{H}, 8.80$. Found: $\mathrm{C}, 52.50 ; \mathrm{H}, 8.67$.

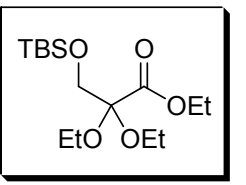

3-(tert-Butyl-dimethyl-silanyloxy)-2,2-diethoxy-propionic acid ethyl ester. To the above alcohol $(2.63 \mathrm{~g}, 12.7 \mathrm{mmol})$ in DMF $(13 \mathrm{~mL})$ was added imidazole $(1.47 \mathrm{~g}, 21.6 \mathrm{mmol})$ followed by TBSCl $(2.68 \mathrm{~g}, 17.8 \mathrm{mmol})$. The reaction was allowed to stir for $12 \mathrm{~h}$, and the mixture was then poured into $\mathrm{H}_{2} \mathrm{O}(45 \mathrm{~mL})$ and extracted with $\mathrm{Et}_{2} \mathrm{O}(2 \times 50 \mathrm{~mL})$. The combined organics were washed with brine, dried over anhydrous $\mathrm{MgSO}_{4}$, filtered, and concentrated under reduced pressure to give a clear liquid that was distilled (98-105 ${ }^{\circ} \mathrm{C}, 5$ torr) to give $3.4 \mathrm{~g}(84 \%)$ of the title compound as a clear liquid. IR (neat) 2978, 2858, 1763, 1740, 1473, $1130 \mathrm{~cm}^{-1}$; ${ }^{1} \mathrm{H}$ NMR (300 MHz, $\left.\mathrm{CDCl}_{3}\right) \delta 0.04$ (s, 6H), 0.86 (s, $9 \mathrm{H}), 1.23(\mathrm{t}, J=7.2 \mathrm{~Hz}, 6 \mathrm{H}), 1.31(\mathrm{t}, J=6.9 \mathrm{~Hz}, 3 \mathrm{H}), 3.43-3.53(\mathrm{~m}, 2 \mathrm{H}), 3.58-3.69(\mathrm{~m}, 2 \mathrm{H})$, $3.85(\mathrm{~s}, 2 \mathrm{H}), 4.25$ (q, $J=6.9 \mathrm{~Hz}, 2 \mathrm{H}) ;{ }^{13} \mathrm{C}$ NMR $\left(75 \mathrm{MHz}, \mathrm{CDCl}_{3}\right) \delta 168.6,101.1,63.2,61.3$, 57.9, 25.7, 18.2, 15.2, 14.2, -5.6; Anal. Calc'd for $\mathrm{C}_{15} \mathrm{H}_{32} \mathrm{O}_{5} \mathrm{Si}$ : C, 56.21; $\mathrm{H}, 10.06$. Found: C, 56.36; H, 9.89 .

\section{General Procedure for Dibal Reduction of Pyruvate Monoacetals.}

To the corresponding ester in $\mathrm{CH}_{2} \mathrm{Cl}_{2}(0.5 \mathrm{M})$ at $-78{ }^{\circ} \mathrm{C}$ was added Dibal-H (2.2 equiv, $1 \mathrm{M}$ in hexanes) dropwise over $1 \mathrm{~h}$. After an additional $20 \mathrm{~min}, \mathrm{MeOH}$ was added dropwise over 20 min to quench excess Dibal-H. Saturated aqueous Rochelle salt and $\mathrm{Et}_{2} \mathrm{O}$ were added. The mixture was allowed to warm to room temperature and stir for $45 \mathrm{~min}$ under vigorous stirring. If necessary, $2 \mathrm{~N}$ aqueous $\mathrm{NaOH}$ (1 drop) was added to break up emulsions. The layers were separated and the aqueous phase was extracted with $\mathrm{Et}_{2} \mathrm{O}$. The combined organic layers were washed with brine, dried over anhydrous $\mathrm{MgSO}_{4}$, filtered, and concentrated under reduced pressure to give a clear liquid that was purified by silica gel chromatography followed by vacuum distillation to give the aldehyde as a clear liquid.

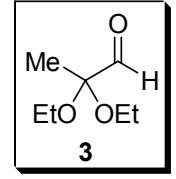

2,2-Diethoxy-propionaldehyde (3). The corresponding ester (10.0 g, $53 \mathrm{mmol})$ was reduced with Dibal-H utilizing the general procedure to give $5.6 \mathrm{~g}(72 \%)$ of aldehyde 3 as a clear liquid after silica gel chromatography eluting with $20 \% \mathrm{Et}_{2} \mathrm{O}$ in pet. ether 
followed by vacuum distillation (32 Torr, $66^{\circ} \mathrm{C}$ ). IR (neat) 2980, 2934, 2893, 1749, 1445, 1376, 1139, $1051 \mathrm{~cm}^{-1} ;{ }^{1} \mathrm{H}$ NMR (500 MHz, $\mathrm{CDCl}_{3}$ ) $\delta 1.24$ (t, $\left.J=12.0 \mathrm{~Hz}, 6 \mathrm{H}\right), 1.37$ (s, 3H), 3.50-3.63 $(\mathrm{m}, 4 \mathrm{H}), 9.49$ (s, 1H); ${ }^{13} \mathrm{C}$ NMR $\left(\mathrm{CDCl}_{3}, 75 \mathrm{MHz}\right) \delta 15.3,18.8,57.6,100.3$, 199.6; Anal. Calc'd for $\mathrm{C}_{7} \mathrm{H}_{14} \mathrm{O}_{3}$ : C, 57.51; $\mathrm{H}, 9.65$. Found: $\mathrm{C}, 57.29 ; \mathrm{H}, 9.47$.

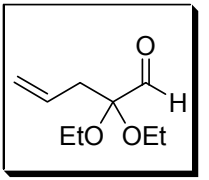

2,2-Diethoxy-pent-4-enal. The corresponding ester $(2.0 \mathrm{~g}, 9.26 \mathrm{mmol})$ was reduced with Dibal-H utilizing the general procedure to give $1.06 \mathrm{~g}(67 \%)$ of the title compound as a clear liquid boiling at $85^{\circ} \mathrm{C}$ (30 Torr). IR (neat) 3081, 2980, 2894, 2819, 1749, 1644, 1443, 1392, 1372, 1160, 1058, $922 \mathrm{~cm}^{-1} ;{ }^{1} \mathrm{H}$ NMR (300 MHz, $\left.\mathrm{CDCl}_{3}\right)$ $\delta 1.24(\mathrm{t}, J=7.2 \mathrm{~Hz}, 6 \mathrm{H}), 2.59(\mathrm{~d}, J=7.2 \mathrm{~Hz}, 2 \mathrm{H}), 3.47-3.66(\mathrm{~m}, 4 \mathrm{H}), 5.08(\mathrm{~s}, 1 \mathrm{H}), 5.13(\mathrm{~s}, 1 \mathrm{H})$, 5.59-5.73 (m, 1H), 9.47 (s, 1H); ${ }^{13} \mathrm{C}$ NMR $\left(\mathrm{CDCl}_{3}, 75 \mathrm{MHz}\right) \delta 200.6,130.3,119.4,101.2,57.6$, 37.5, 15.3. Anal. Calc'd for $\mathrm{C}_{9} \mathrm{H}_{16} \mathrm{O}_{3}$ : C, 62.77; H, 9.36. Found: C, 62.58; $\mathrm{H}, 9.27$.

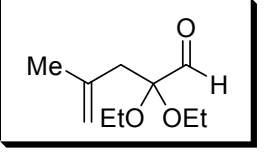

2,2-Diethoxy-4-methyl-pent-4-enal. The corresponding ester $(2.34 \mathrm{~g}$, $10.1 \mathrm{mmol}$ ) was reduced with Dibal-H utilizing the general procedure to give the title compound as a clear liquid. IR (neat) 3078, 2979, 2932, 2897, 1750, 1647, 1444, 1130, $899 \mathrm{~cm}^{-1} ;{ }^{1} \mathrm{H}$ NMR (300 MHz, $\left.\mathrm{CDCl}_{3}\right) \delta 1.23(\mathrm{t}, J=7.2 \mathrm{~Hz}, 3 \mathrm{H}), 1.74(\mathrm{~s}, 3 \mathrm{H})$, $2.58(\mathrm{~s}, 2 \mathrm{H}), 3.45-3.65(\mathrm{~m}, 4 \mathrm{H}), 4.80(\mathrm{~s}, 1 \mathrm{H}), 4.84(\mathrm{~s}, 1 \mathrm{H})$; Anal. Calc'd for $\mathrm{C}_{10} \mathrm{H}_{18} \mathrm{O}_{3}: \mathrm{C}, 64.49$; H, 9.74 Found: C, 64.36; $H, 9.58$.

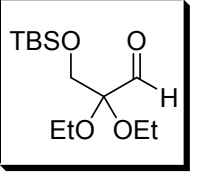

3-(tert-Butyl-dimethyl-silanyloxy)-2,2-diethoxy-propionaldehyde. The ester ( $3.05 \mathrm{~g}, 9.53 \mathrm{mmol})$ was reduced with Dibal-H utilizing the general procedure to give $2.1 \mathrm{~g}(80 \%)$ of a clear liquid. ${ }^{1} \mathrm{H}$ NMR $\left(300 \mathrm{MHz}, \mathrm{CDCl}_{3}\right) \delta 0.03(\mathrm{~s}, 6 \mathrm{H}), 0.86$ $(\mathrm{s}, 9 \mathrm{H}), 1.23(\mathrm{t}, J=6.9 \mathrm{~Hz}, 6 \mathrm{H}), 3.47-3.57(\mathrm{~m}, 2 \mathrm{H}), 3.58-3.68(\mathrm{~m}, 2 \mathrm{H}), 3.79(\mathrm{~s}, 2 \mathrm{H}), 9.56(\mathrm{~s}, 1 \mathrm{H})$; ${ }^{13} \mathrm{C} \mathrm{NMR}\left(\mathrm{CDCl}_{3}, 75 \mathrm{MHz}\right) \delta 202.0,100.6,62.6,57.5,25.6,18.1,15.3,-5.7$; IR (neat) 2978, 2931, 2859, 1751, 1472, 1391, 1124, $838 \mathrm{~cm}^{-1}$; Anal. Calc'd for $\mathrm{C}_{13} \mathrm{H}_{28} \mathrm{O}_{4} \mathrm{Si}: \mathrm{C}, 56.48 ; \mathrm{H}, 10.21$. Found: C, 56.60; H, 10.22 .

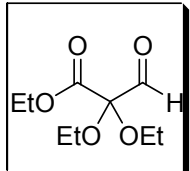

2,2-Diethoxy-3-oxo-propionic acid ethyl ester. To the corresponding alcohol $(1.3 \mathrm{~g}, 6.3 \mathrm{mmol})$ in $\mathrm{CH}_{2} \mathrm{Cl}_{2}(30 \mathrm{~mL})$ was added Dess-Martin periodinane (3.5, $8.3 \mathrm{mmol})$. After $1 \mathrm{~h}$, the reaction was portioned between saturated aqueous $\mathrm{NaHCO}_{3}$ and $\mathrm{Et}_{2} \mathrm{O}$. The layers were separated and the aqueous phase was washed with brine, dried over anhydrous $\mathrm{MgSO}_{4}$, filtered, and concentrated under reduced pressure to give a clear 
liquid that was purified by silica gel chromatography. IR (neat) 2983, 2939, 2902, 1748 (broad), 1446, 1394, 1371, 1130; ${ }^{1} \mathrm{H}$ NMR (300 MHz, $\left.\mathrm{CDCl}_{3}\right) \delta 1.29(\mathrm{t}, J=7.2 \mathrm{~Hz}, 6 \mathrm{H}), 1.30$ (t, $J=7.2 \mathrm{~Hz}$, $3 \mathrm{H}), 3.55-3.71(\mathrm{~m}, 4 \mathrm{H}), 4.28(\mathrm{q}, J=7.2 \mathrm{~Hz}, 2 \mathrm{H}), 9.53(\mathrm{~s}, 1 \mathrm{H}) ;{ }^{13} \mathrm{C} \mathrm{NMR}\left(\mathrm{CDCl}_{3}, 75 \mathrm{MHz}\right)$ $\delta$ 195.2, 165.2, 99.5, 62.3, 59.7, 15.1, 14.0; Anal. Calc'd for $\mathrm{C}_{9} \mathrm{H}_{16} \mathrm{O}_{5}: \mathrm{C}, 52.93 ; \mathrm{H}, 7.90$. Found: C, $52.77 ; \mathrm{H}, 8.12$.

\section{General Procedure for the Synthesis of Ynones from $\mathbf{N}$-methoxy- $\mathbf{N}$-methyl acetamide.}

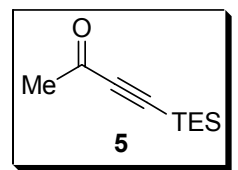

4-Triethylsilanyl-but-3-yn-2-one (5). To triethylsilyl acetylene $(5.5 \mathrm{~g}, 39.2 \mathrm{mmol}$, $7.0 \mathrm{~mL})$ in THF $(80 \mathrm{~mL})$ at $-78{ }^{\circ} \mathrm{C}$ was added $n$-BuLi $(1.4 \mathrm{M}$ in hexanes, $31.0 \mathrm{~mL}$, $43.1 \mathrm{mmol}$ ) dropwise over $10 \mathrm{~min}$. After $10 \mathrm{~min}$, the $-78^{\circ} \mathrm{C}$ bath was replaced by an ice-bath. After 30 min the reaction was recooled to $-78{ }^{\circ} \mathrm{C}$. Freshly distilled $\mathrm{N}$-methoxy$N$-methyl acetamide $(4.8 \mathrm{~g}, 47.0 \mathrm{mmol}, 5.0 \mathrm{~mL})$ was then added dropwise over $10 \mathrm{~min}$. After $1 \mathrm{~h}$ the $-78{ }^{\circ} \mathrm{C}$ bath was warmed to $-10^{\circ} \mathrm{C}$. The reaction was quenched with $\mathrm{H}_{2} \mathrm{O}(100 \mathrm{~mL})$ and extracted with $\mathrm{Et}_{2} \mathrm{O}(2 \times 100 \mathrm{~mL})$. The organic layers were combined, washed with saturated $\mathrm{NaHCO}_{3}$ and brine, then dried $\left(\mathrm{MgSO}_{4}\right)$, filtered and concentrated to a brown oil. The oil was filtered through a short column eluting with $5 \% \mathrm{Et}_{2} \mathrm{O}$ in petroleum ether. The fractions containing the desired product were concentrated to a residue. Vacuum distillation $(5 \mathrm{~mm} \mathrm{Hg})$ provided $6.1 \mathrm{~g}(86 \%)$ of a clear liquid. IR (neat) 2959, 2878, 2149, 1682, 1459, 1416, 1357 , 1195, 1018, 831 $\mathrm{cm}^{-1} ;{ }^{1} \mathrm{H}$ NMR (300 MHz, $\left.\mathrm{CDCl}_{3}\right) \delta 2.36(\mathrm{~s}, 3 \mathrm{H}), 1.01(\mathrm{t}, J=7.8 \mathrm{~Hz}, 9 \mathrm{H}), 0.68$ (q, $J=7.8 \mathrm{~Hz}, 6 \mathrm{H}) ;{ }^{13} \mathrm{C}$ NMR $\left(75 \mathrm{MHz} \mathrm{CDCl}_{3}\right)$ 184.2, 103.6, 95.5, 32.6, 7.2, 3.7; Anal. Calc'd for $\mathrm{C}_{7} \mathrm{H}_{14} \mathrm{O}_{3}: \mathrm{C}, 65.87 ; \mathrm{H}, 9.95$. Found: C, 66.06; $\mathrm{H}, 9.80$.

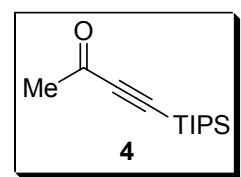

4-Triisopropylsilanyl-but-3-yn-2-one (4). Ynone 4 was prepared according to the general procedure and isolated as a colorless liquid in $80 \%$ yield. IR (neat) 2946, 2868, 2147, 1996, 1684, 1463, 1356, $1196 \mathrm{~cm}^{-1} ;{ }^{1} \mathrm{H}$ NMR $\left(300 \mathrm{MHz}, \mathrm{CDCl}_{3}\right) \delta 2.38(\mathrm{~s}, 3 \mathrm{H}), 1.09-1.13(\mathrm{~m}, 21 \mathrm{H})$.

General Procedure for Dinuclear Zn(II) Catalyst Preparation. Ligand 4 (64 mg, $0.10 \mathrm{mmol}$ ) was azeotroped with $\mathrm{PhCH}_{3}(2 \times 2 \mathrm{~mL})$, then dissolved in THF $(1.0 \mathrm{~mL})$ and cooled to $0{ }^{\circ} \mathrm{C}$. $\mathrm{Et}_{2} \mathrm{Zn}(0.20 \mathrm{~mL}, 1.0 \mathrm{M}$ in hexanes, $0.20 \mathrm{mmol})$ was added and the ice bath was removed. The catalyst solution was allowed to stir at room temperature for 20 min then used as a $0.08 \mathrm{M}$ solution. 
General Procedure for Dinuclear Zn(II) Catalyzed Aldol Reaction on a 1.0 mmol scale. $4 \AA$ crushed molecular sieves $(0.100 \mathrm{~g}, 0.100 \mathrm{~g} / \mathrm{mmol})$ were flame-dried under vacuum. THF and ketone were added such that the total volume is $3.5 \mathrm{~mL}$. Aldehyde $(1.0 \mathrm{mmol})$ was added and the reaction was cooled to the appropriate temperature. For a reaction requiring $5 \mathrm{~mol} \%$ catalyst, $0.60 \mathrm{~mL}$ of the catalyst solution was added. After the reaction was judged complete the contents were poured into $\mathrm{pH} 7$ phosphate buffer and $\mathrm{Et}_{2} \mathrm{O}$. The layers were separated and the aqueous layer was extracted with $\mathrm{Et}_{2} \mathrm{O}(1 \times)$. The combined organics were washed brine, dried over anhydrous $\mathrm{MgSO}_{4}$, filtered, and concentrated to give a yellow oil. Purification on silica gel eluting with $\mathrm{Et}_{2} \mathrm{O}$ in pet. ether (gradient to remove excess ketone) typically gave the aldol product as a clear oil.

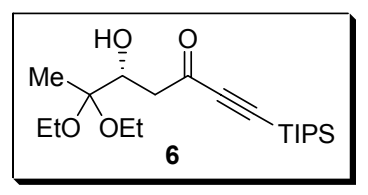

6,6-Diethoxy-(5R)-hydroxy-1-triisopropylsilanyl-hept-1-yn-3-one (6). HPLC: 99:1 heptane:i-PrOH, $1.0 \mathrm{ml} / \mathrm{min}, 254 \mathrm{~nm}$, OD column, $t_{\mathrm{R}} 6.48$ and $7.59 \mathrm{~min}$;. $\mathrm{R}_{\mathrm{f}} 0.33$ (30\% $\mathrm{Et}_{2} \mathrm{O}$ in Pet. Ether); IR (neat) 3490, 2945, 2868, 2148, 1996, 1682, 1463, 1387, 1228, 1080, $883 \mathrm{~cm}^{-1}$; ${ }^{1} \mathrm{H} \mathrm{NMR}\left(300 \mathrm{MHz}, \mathrm{CDCl}_{3}\right) \delta 4.39$ (dt, $J=9.5,2.5 \mathrm{~Hz}, 1 \mathrm{H}), 3.47-3.56(\mathrm{~m}, 4 \mathrm{H}) ;{ }^{13} \mathrm{C} \mathrm{NMR}\left(75 \mathrm{MHz}, \mathrm{CDCl}_{3}\right) \delta 185.4,111.4,103.9,101.4$, 95.8, 68.6, 56.1, 55.7, 47.6, 18.3, 17.2, 15.23, 15.15, 10.9;

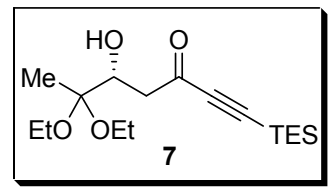

6,6-Diethoxy-(5R)-hydroxy-1-triethylsilanyl-hept-1-yn-3-one (7). Ligand $1(0.292 \mathrm{~g}, 0.458 \mathrm{mmol})$ was azeotroped with $\mathrm{PhCH}_{3}(2 \times 5 \mathrm{~mL})$, then dissolved in THF $(4.5 \mathrm{~mL})$ and cooled to $0{ }^{\circ} \mathrm{C}$. $\mathrm{Et}_{2} \mathrm{Zn}(0.915 \mathrm{~mL}, 1.0 \mathrm{M}$ in hexanes, $0.915 \mathrm{mmol}$ ) was added and the ice bath was removed. The catalyst solution was allowed to stir at room temperature for $20 \mathrm{~min}$ then used as a $0.08 \mathrm{M}$ solution. $4 \AA$ crushed molecular sieves $(2.40 \mathrm{~g}, 100 \mathrm{mg} / \mathrm{mmol})$ were flame-dried under vacuum. THF $(75 \mathrm{~mL})$ was added followed by $5(4.37 \mathrm{~g}, 5.0 \mathrm{~mL}, 24.0 \mathrm{mmol})$ and $3(2.92 \mathrm{~g}, 3.14 \mathrm{~mL}, 20.0 \mathrm{mmol})$. The reaction mixture was cooled to $0{ }^{\circ} \mathrm{C}$ and $5.0 \mathrm{~mL}$ of the above catalyst solution was added over $5 \mathrm{~min}$. The ice bath was removed and the reaction was allowed to proceed at room temperature for $17 \mathrm{~h}$. The reaction was then poured into $\mathrm{pH} 7$ phosphate buffer and $\mathrm{Et}_{2} \mathrm{O}$. The layers were separated and the aqueous layer was extracted with $\mathrm{Et}_{2} \mathrm{O}(1 \times)$. The combined organics were washed with saturated aqueous $\mathrm{NaHCO}_{3}$ and brine, then dried over anhydrous $\mathrm{MgSO}_{4}$, filtered, and concentrated to give a yellow oil. Purification on silica gel eluting with $10 \%-30 \% \mathrm{Et}_{2} \mathrm{O}$ in pet. ether gave $4.7 \mathrm{~g}(72 \%)$ of 7 as a clear oil in 99\% ee. HPLC: 99.5:0.5 heptane:i-PrOH, 1.0 $\mathrm{ml} / \mathrm{min}, 254 \mathrm{~nm}$, OD column, $t_{\mathrm{R}} 17.18$ and $19.30 \mathrm{~min} ; . \mathrm{R}_{\mathrm{f}} 0.33\left(30 \% \mathrm{Et}_{2} \mathrm{O}\right.$ in pet. ether); $[\alpha]_{\mathrm{D}}{ }^{24}$ $+11.3^{\circ}$ (c=1.4, $\mathrm{CHCl}_{3}$ ); IR (neat) 3400, 2959, 2878, 2149, 1682, 1391, 1234, $1082 \mathrm{~cm}^{-1}$; 
${ }^{1} \mathrm{H}$ NMR $\left(300 \mathrm{MHz} \mathrm{CDCl}_{3}\right) \delta 0.67(\mathrm{q}, J=8.1 \mathrm{HZ}, 6 \mathrm{H}), 1.01(\mathrm{t}, J=7.8 \mathrm{~Hz}, 9 \mathrm{H}), 1.15(\mathrm{t}, J=6.9 \mathrm{~Hz}$, $3 \mathrm{H}), 1.19(\mathrm{t}, J=6.9 \mathrm{~Hz}, 3 \mathrm{H}), 1.26(\mathrm{~s}, 3 \mathrm{H}), 2.37(\mathrm{~s}, 1 \mathrm{H}), 2.68(\mathrm{dd}, J=9.3,16.5 \mathrm{~Hz}, 1 \mathrm{H}), 2.82$ (dd, $J=1.8,16.5 \mathrm{~Hz}, 1 \mathrm{H}), 3.42-3.56(\mathrm{~m}, 4 \mathrm{H}), 4.36(\mathrm{~d}, J=9.3 \mathrm{~Hz}, 1 \mathrm{H}) ;{ }^{13} \mathrm{C} \mathrm{NMR}\left(75 \mathrm{MHz} \mathrm{CDCl}_{3}\right)$ $\delta 185.6,103.2$, 101.6, 96.6, 68.7, 56.3, 55.9, 47.6, 17.4, 15.4, 7.3, 3.8; Anal. Calc'd for $\mathrm{C}_{17} \mathrm{H}_{34} \mathrm{O}_{4} \mathrm{Si}: \mathrm{C}, 62.15 ; \mathrm{H}, 9.82$. Found: C, 62.39; $\mathrm{H}, 9.63$.

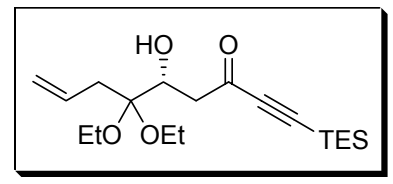

\section{6,6-Diethoxy-(5R)-hydroxy-1-triethylsilanyl-non-8-en-1-yn-3-one.}

Utilizing the general procedure with the following quantities: 2,2-diethoxy-pent-4-enal $(0.172 \mathrm{~g}, 0.187 \mathrm{~mL}, 1.0 \mathrm{mmol}), 5(0.364 \mathrm{~g}$, $0.42 \mathrm{~mL}, 2.0 \mathrm{mmol}), 5 \mathrm{~mol} \% 2$, in THF $(3.0 \mathrm{~mL})$ at room temperature gave the title compound in $75 \%$ yield and in $>99 \%$ ee after $4 \mathrm{~h}$. HPLC 99:1 heptane: $\mathrm{PrOH}, 0.8 \mathrm{ml} / \mathrm{min}, 254 \mathrm{~nm}$, OD column, $t_{\mathrm{R}} 7.56$ (major) and 8.44 (minor) min; $\mathrm{R}_{\mathrm{f}} 0.41$ (25\% $\mathrm{Et}_{2} \mathrm{O}$ in Pet. Ether); $[\alpha]_{\mathrm{D}}{ }^{24}-10.3^{\circ}$ (c = 0.52, $\mathrm{CHCl}_{3}$ ); IR (neat) 3511, 3078, 2958, 2878, 2149, 1996, 1679, 1640, 1390, 1053, 1018 $\mathrm{cm}^{-1}$; ${ }^{1} \mathrm{H}$ NMR $\left(300 \mathrm{MHz}, \mathrm{CDCl}_{3}\right) \delta 0.68(\mathrm{q}, J=7.8 \mathrm{~Hz}, 6 \mathrm{H}), 1.01(\mathrm{t}, \mathrm{J}=7.8 \mathrm{~Hz}, 9 \mathrm{H}), 1.17$ (t, $J=6.9 \mathrm{~Hz}, 3 \mathrm{H})$ overlapping with $1.19(\mathrm{t}, J=6.9 \mathrm{~Hz}, 3 \mathrm{H}), 2.43(\mathrm{~d}, J=3.5 \mathrm{~Hz}, 1 \mathrm{H}), 2.41-2.42(\mathrm{~m}$, $1 \mathrm{H}), 2.46-2.58(\mathrm{~m}, 2 \mathrm{H}), 2.78(\mathrm{dd}, J=9.0,16.5 \mathrm{~Hz}, 1 \mathrm{H}), 2.84-2.90(\mathrm{~m}, 1 \mathrm{H}), 3.44-3.67(\mathrm{~m}, 4 \mathrm{H})$, 4.40 (ddd, $J=3.3,3.3,9.0 \mathrm{~Hz}, 1 \mathrm{H}), 5.06(\mathrm{~s}, 1 \mathrm{H}), 5.12(\mathrm{dd}, J=1.8,17.4 \mathrm{~Hz}, 1 \mathrm{H}), 5.83-5.96(\mathrm{~m}$, $1 \mathrm{H}) ;{ }^{13} \mathrm{C}$ NMR $\left(75 \mathrm{MHz}, \mathrm{CDCl}_{3}\right) \delta 185.7,133.3,117.6,103.2,101.0,96.6,69.9,56.8,56.6,47.6$, 37.5, 15.4, 7.3, 3.8; Anal. Calc'd for $\mathrm{C}_{19} \mathrm{H}_{34} \mathrm{O}_{4} \mathrm{Si}$ : C, 64.36; $\mathrm{H}$ 9.67. Found: $\mathrm{C}, 64.12 ; \mathrm{H}, 9.46$.

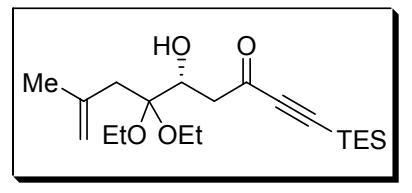

6,6-Diethoxy-(5R)-hydroxy-8-methyl-1-triethylsilanyl-non-8-en-1yn-3-one. Utilizing the general procedure with the following quantities: 2,2-diethoxy-4-methyl-pent-4-enal $(0.186 \mathrm{~g}, 0.173 \mathrm{~mL}, 1.0 \mathrm{mmol}), 5$ $(0.45 \mathrm{~g}, 0.52 \mathrm{~mL}, 2.5 \mathrm{mmol}), 5 \mathrm{~mol} \% 2$, in THF $(3.0 \mathrm{~mL})$ at $0{ }^{\circ} \mathrm{C}$ gave the title compound in $85 \%$ yield and in $>99 \%$ ee after 22.5 h. HPLC 99.7:0.3 heptane:iPrOH, $1.0 \mathrm{ml} / \mathrm{min}, 254 \mathrm{~nm}$, OD column, $t_{R} 11.67$ and $13.37 \mathrm{~min} ; \mathrm{R}_{\mathrm{f}} 0.27$ (15\% Et $\mathrm{t}_{2} \mathrm{O}$ in Pet Ether); IR (neat) 3543, 3075, 2958, 2878, 2150, 1996, 1682, 1644, 1456, 1391, 1235, cm ${ }^{-1} ;{ }^{1} \mathrm{H}$ NMR $\left(500 \mathrm{MHz}, \mathrm{CDCl}_{3}\right) \delta 0.67$ (q, $J=8.0 \mathrm{~Hz}, 6 \mathrm{H}), 1.01(\mathrm{t}, J=8.0 \mathrm{~Hz}, 9 \mathrm{H}), 1.18(\mathrm{t}, J=7.0 \mathrm{~Hz}, 3 \mathrm{H})$ overlapping with $1.18(\mathrm{t}$, $J=7.0 \mathrm{~Hz}, 3 \mathrm{H}), 1.85(\mathrm{~s}, 3 \mathrm{H}), 2.39(\mathrm{~d}, J=15.0 \mathrm{~Hz}, 1 \mathrm{H}), 2.50(\mathrm{~d}, J=4.0 \mathrm{~Hz}, 1 \mathrm{H}), 2.51$ (d, $J=14.5 \mathrm{~Hz}, 1 \mathrm{H}), 2.81(\mathrm{dd}, J=9.0,16.0 \mathrm{~Hz}, 1 \mathrm{H}), 2.90(\mathrm{dd}, J=3.0,16.0 \mathrm{~Hz}, 1 \mathrm{H}), 3.51-3.69(\mathrm{~m}$, $4 \mathrm{H}), 4.43(\mathrm{ddd}, J=3.0,4.0,9.0 \mathrm{~Hz}, 1 \mathrm{H}), 4.88(\mathrm{~d}, J=1.0 \mathrm{~Hz}, 2 \mathrm{H}) ;{ }^{13} \mathrm{C} \mathrm{NMR}\left(75 \mathrm{MHz} \mathrm{CDCl}_{3}\right) \delta$ 185.8, 141.9, 115.3, 103.2, 101.3, 96.4, 70.6, 56.8, 47.8, 40.7, 23.6, 15.3, 15.25, 7.3, 3.8; Anal. Calc'd for $\mathrm{C}_{20} \mathrm{H}_{36} \mathrm{O}_{4}$ Si: C, 65.17; $\mathrm{H}, 9.84$. Found: C, 65.06; H, 9.65. 


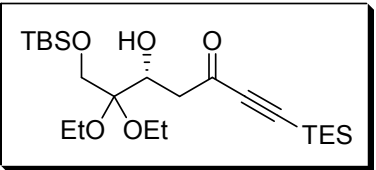

7-(tert-Butyl-dimethyl-silanyloxy)-6,6-diethoxy-(5R)-hydroxy-1triethylsilanyl-hept-1-yn-3-one. Utilizing the general procedure with the following quantities: 3-(tert-butyl-dimethyl-silanyloxy)-2,2-diethoxypropionaldehyde $(0.276 \mathrm{~g}, 0.300 \mathrm{~mL}, 1.0 \mathrm{mmol}), 5(0.218 \mathrm{~g}, 0.250 \mathrm{~mL}, 1.2 \mathrm{mmol}), 4 \mathrm{~mol} \% 2$, in THF $(3.0 \mathrm{~mL})$ at room temperature gave the title compound in $73 \%$ yield and in $>98 \%$ ee after $5 \mathrm{~h}$. HPLC 98:2 heptane: $\mathrm{PrOH}, 0.5 \mathrm{ml} / \mathrm{min}, 254 \mathrm{~nm}$, AD column, $t_{\mathrm{R}} 9.17$ and $10.29 \mathrm{~min} ; \mathrm{R}_{\mathrm{f}} 0.46$ (25\% $\mathrm{Et}_{2} \mathrm{O}$ in Pet. Ether); $[\alpha]_{\mathrm{D}}^{24}+15.2^{\circ}\left(\mathrm{c}=2.5, \mathrm{CHCl}_{3}\right)$; IR (neat) 3520, 2957, 2886, 2149, 1996, 1681, 1464, 1390, $1093 \mathrm{~cm}^{-1} ;{ }^{1} \mathrm{H}$ NMR $\left(300 \mathrm{MHz}, \mathrm{CDCl}_{3}\right) \delta 0.09(\mathrm{~s}, 6 \mathrm{H}), 0.66(\mathrm{q}, J=7.8 \mathrm{~Hz}, 6 \mathrm{H})$, $0.91(\mathrm{~s}, 9 \mathrm{H}), 1.01(\mathrm{q}, J=7.8 \mathrm{~Hz}, 9 \mathrm{H}), 1.15(\mathrm{t}, J=7.2 \mathrm{~Hz}, 3 \mathrm{H})$ overlapping with $1.20(\mathrm{t}, J=7.2 \mathrm{~Hz}$, $3 \mathrm{H}), 2.93-2.96(\mathrm{~m}, 3 \mathrm{H}), 3.48-3.60(\mathrm{~m}, 4 \mathrm{H}), 3.65(\mathrm{~d}, J=11.1 \mathrm{~Hz}, 1 \mathrm{H}), 3.80(\mathrm{~d}, J=11.1 \mathrm{~Hz}, 1 \mathrm{H})$, 4.39-4.45 (m, 2H); ${ }^{13} \mathrm{C}$ NMR $\left(75 \mathrm{MHz}, \mathrm{CDCl}_{3}\right) \delta 186.4,128.0,103.4,99.8,96.1,68.7,62.656 .5$, 56.1, 48.8, 25.7, 18.0, 15.3, 7.3, 3.8, -5.7, -5.8; Anal. Calc'd for $\mathrm{C}_{23} \mathrm{H}_{46} \mathrm{O}_{5} \mathrm{Si}_{2}: \mathrm{C}, 60.21 ; \mathrm{H}, 10.11$;. Found: C, 60.42; H, 9.97.

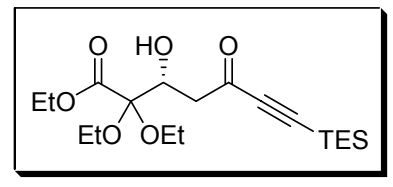

2,2-Diethoxy-3-hydroxy-(5R)-oxo-7-triethylsilanyl-hept-6-ynoic acid ethyl ester. Utilizing the general procedure with the following quantities: 2,2-diethoxy-3-oxo-propionic acid ethyl ester $(0.102 \mathrm{~g}, 0.096 \mathrm{~mL}$, $0.5 \mathrm{mmol}), 5(0.217 \mathrm{~g}, 0.250 \mathrm{~mL}, 1.20 \mathrm{mmol}), 5 \mathrm{~mol} \% 2$, in THF $(1.6 \mathrm{~mL})$ at $0{ }^{\circ} \mathrm{C}$ gave the title compound in $68 \%$ yield and $37 \%$ ee after $4.25 \mathrm{~h}$. HPLC 98:2 heptane: $\mathrm{PrOH}, 0.5 \mathrm{ml} / \mathrm{min}$, $254 \mathrm{~nm}, \mathrm{AD}$ column, $t_{\mathrm{R}} 26.5$ and $30.7 \mathrm{~min}$; $\mathrm{R}_{\mathrm{f}} 0.44$ (50\% $\mathrm{Et}_{2} \mathrm{O}$ in Pet. Ether); IR (neat) 3511, 2959, 2878, 2148, 1996, 1747, 1680, 1393, $1076 \mathrm{~cm}^{-1} ;{ }^{1} \mathrm{H} \mathrm{NMR}\left(300 \mathrm{MHz} \mathrm{CDCl}_{3}\right) \delta 0.68$ (q, $J=7.8 \mathrm{~Hz}, 6 \mathrm{H}), 1.01(\mathrm{t}, J=7.5 \mathrm{~Hz}, 9 \mathrm{H}), 1.22(\mathrm{t}, J=7.1 \mathrm{~Hz}, 3 \mathrm{H}), 1.27(\mathrm{t}, J=7.1 \mathrm{~Hz}, 3 \mathrm{H}), 1.34(\mathrm{t}$, $J=7.2 \mathrm{~Hz}, 3 \mathrm{H}), 2.62(\mathrm{~d}, J=3.9 \mathrm{~Hz}, 1 \mathrm{H}), 2.78(\mathrm{dd}, J=9.6,17.4 \mathrm{~Hz}, 1 \mathrm{H}), 3.01(\mathrm{dd}, J=2.1$, $17.4 \mathrm{~Hz}, 1 \mathrm{H}), 3.56-3.64(\mathrm{~m}, 3 \mathrm{H}), 3.66-3.77(\mathrm{~m}, 1 \mathrm{H}), 4.29(\mathrm{q}, J=7.2 \mathrm{~Hz}, 2 \mathrm{H}), 4.56$ (ddd, $J=2.4$, 4.2, 9.6Hz, $1 \mathrm{H}) ;{ }^{13} \mathrm{C}$ NMR $\left(75 \mathrm{MHz}, \mathrm{CDCl}_{3}\right) \delta 185.1,167.7,103.0,101.5,96.8,68.5,61.7,59.3$, 58.4, 47.4, 15.2, 15.1, 14.1, 7.2, 3.7; Anal. Calc'd for $\mathrm{C}_{19} \mathrm{H}_{34} \mathrm{O}_{6} \mathrm{Si}: \mathrm{C}, 59.04$; $\mathrm{H}, 8.87$. Found: C, $59.02 ; \mathrm{H}, 8.68$.

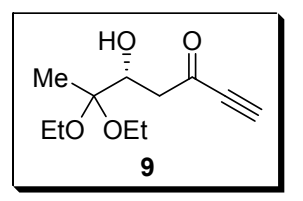

6,6-Diethoxy-(5R)-hydroxy-hept-1-yn-3-one (9). HPLC 97:3 heptane:iPrOH, $1.0 \mathrm{ml} / \mathrm{min}, 220 \mathrm{~nm}, \mathrm{AD}$ column, $t_{\mathrm{R}} 15.43$ and $16.55 \mathrm{~min}$; IR (neat) 3490, 3251, 2978, 2931, 2093, 1686, 1390, 1231, $1082 \mathrm{~cm}^{-1} ;{ }^{1} \mathrm{H}$ NMR (400 MHz, $\left.\mathrm{CDCl}_{3}\right) \delta 1.16(\mathrm{t}, J=7.2 \mathrm{~Hz}, 3 \mathrm{H}), 1.20(\mathrm{t}, J=7.2 \mathrm{~Hz}, 3 \mathrm{H}), 1.27(\mathrm{~s}, 3 \mathrm{H}), 2.36(\mathrm{~s}, 1 \mathrm{H}), 2.72$ (dd, $J=16.4,9.6 \mathrm{~Hz}, 1 \mathrm{H}), 2.84(\mathrm{dd}, J=16.4,2.4 \mathrm{~Hz}, 1 \mathrm{H}), 3.28(\mathrm{~s}, 1 \mathrm{H}), 3.44-3.57(\mathrm{~m}, 4 \mathrm{H}), 4.36(\mathrm{dt}$, 
$J=9.6,2.4 \mathrm{~Hz}, 1 \mathrm{H}) ;{ }^{13} \mathrm{C}$ NMR $\left(100 \mathrm{MHz} \mathrm{CDCl}_{3}\right) \delta 185.4,101.6,81.4,78.9,68.7,56.4,56.0$, 47.5, 17.3, 15.4, 15.3; Anal. Calc'd for $\mathrm{C}_{11} \mathrm{H}_{18} \mathrm{O}_{4}$ : C, 61.66; $\mathrm{H}$ 8.47. Found: $\mathrm{C}, 61.80 ; \mathrm{H}, 8.53$.

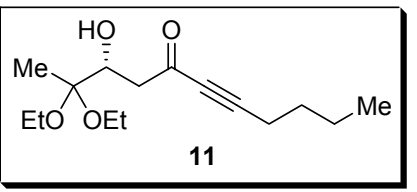

2,2-Diethoxy-(3R)-hydroxy-undec-6-yn-5-one (11). HPLC 98:2 heptane: $\mathrm{PrOH}, 0.5 \mathrm{ml} / \mathrm{min}, 220 \mathrm{~nm}$, OJ column, $t_{\mathrm{R}} 14.79$ and $16.16 \mathrm{~min}$; IR (neat) 3506, 2971, 2933, 2213, 1676, 1390, 1238, 1137, $1054 \mathrm{~cm}^{-1}$; ${ }^{1} \mathrm{H}$ NMR $\left(300 \mathrm{MHz}, \mathrm{CDCl}_{3}\right) \delta 0.93(\mathrm{t}, J=7.2 \mathrm{~Hz}, 3 \mathrm{H}), 1.16(\mathrm{t}, J=7.2 \mathrm{~Hz}, 3 \mathrm{H})$ overlapping with $1.20(\mathrm{t}, J=7.2 \mathrm{~Hz}, 3 \mathrm{H}), 1.27(\mathrm{~s}, 3 \mathrm{H}), 1.38-1.62(\mathrm{~m}, 4 \mathrm{H}), 2.38(\mathrm{~m}, 3 \mathrm{H}), 2.66$ (dd, $J=9.6,16.8 \mathrm{~Hz}, 1 \mathrm{H}), 2.81(\mathrm{~d}, J=16.5 \mathrm{~Hz}, 1 \mathrm{H}), 3.43-3.55(\mathrm{~m}, 4 \mathrm{H}), 4.34(\mathrm{~d}, J=9.6 \mathrm{~Hz}, 1 \mathrm{H})$; ${ }^{13} \mathrm{C}$ NMR $\left(75 \mathrm{MHz}, \mathrm{CDCl}_{3}\right) \delta 186.3,101.6,95.0,80.9,68.7,56.2,55.8,47.5,29.6,21.9,18.6$, 17.3, 15.3, 13.4; Anal. Calc'd for $\mathrm{C}_{15} \mathrm{H}_{26} \mathrm{O}_{4}$ : C, 66.64; $\mathrm{H}$ 9.69. Found: $\mathrm{C}, 66.56$; $\mathrm{H}, 9.42$. 